\title{
An Improved Motorized Corer and Sample Processing System for Frozen Peat
}

\author{
TOMMY NØRNBERG, ${ }^{1}$ MICHAEL E. GOODSITE ${ }^{1,2}$ and WILLIAM SHOTYK ${ }^{3}$
}

(Received 7 July 2003; accepted in revised form 26 January 2004)

\begin{abstract}
An improved corer and associated equipment for obtaining continuous samples of frozen peat are described. We developed the system through laboratory and field trials—on Bathurst Island, Nunavut, Canada in 2000 and Nordvest $\varnothing$, Carey Islands, Greenland, in 2001 - as part of efforts to collect continuous samples of Arctic peat cores for an environmental archive of heavy metal and persistent organic pollutants. A new system for precise slicing of frozen peat cores and accurate volumetric sub-sampling of slices is also described and illustrated, since pre-analytical preparation of the cores is important for accurate trace analyses, as well as for determination of net accumulation rates. The coring system is portable, weighing $26 \mathrm{~kg}$ with no fuel, motor, or samples. The system is designed for Arctic use. It recovers continuous cores up to $10 \mathrm{~m}$ below surface in sections $70 \mathrm{~cm}$ long and $9.7 \mathrm{~cm}$ in diameter, with a cutting head robust enough to penetrate slightly below the organics to probe the substrate. It takes a two-man team approximately 15 minutes per section for sampling and packing. The coring system costs about US $\$ 8000$ in parts and labor, plus the cost of the motor. Its adaptability will make it useful for recovering a broad range of Quaternary materials frozen in the Arctic.
\end{abstract}

Key words: Arctic, frozen peat, coring equipment, permafrost, tundra

RÉSUMÉ. On décrit un carottier perfectionné, ainsi que le matériel auxiliaire, qui permet d'obtenir des échantillons en continu de tourbe gelée. Le système a été mis au point à la suite d'essais en laboratoire et sur le terrain - dans l'île de Bathurst (Canada) en 2000 et à Nordvestø dans les îles Carey (Groenland) en 2001 - dans le cadre de travaux visant à recueillir des échantillons en continu de carottes de tourbe arctique pour obtenir des archives environnementales des métaux lourds et des polluants organiques persistants. En outre, on décrit et on illustre un nouveau système permettant de trancher les carottes de tourbe gelée de façon précise et d'en faire un sous-échantillonnage volumétrique exact, vu l'importance de la préparation des carottes pour effectuer une analyse de traces rigoureuse ainsi que pour déterminer le taux net d'accumulation. Avec un poids de $26 \mathrm{~kg}$ sans carburant, moteur ni échantillons, le système de carottage est portable. Il est conçu pour être utilisé dans l'Arctique. Il retire des échantillons en continu jusqu'à une profondeur de $10 \mathrm{~m}$ de la surface, en sections de $70 \mathrm{~cm}$ de long et de $9,7 \mathrm{~cm}$ de diamètre, grâce à une tête de coupe assez robuste pour pénétrer légèrement sous les dépôts organiques et sonder le substratum. Il faut environ 15 minutes à une équipe de deux hommes pour effectuer l'échantillonnage et l'emballage d'une section. Le prix du système de carottage est d'environ 8000 \$ US en pièces et main-d'œuvre, plus le coût du moteur. Son adaptabilité le rendra utile pour extraire une vaste gamme de matériaux du quaternaire congelés dans l'Arctique.

Mots clés: Arctique, tourbe gelée, équipement de carottage, pergélisol, toundra

Traduit pour la revue Arctic par Nésida Loyer.

\section{INTRODUCTION}

Recent research using peat deposits in the High Arctic as archives of environmental contaminants has required a coring system to obtain continuous, undisturbed cores from deposits that are typically more than $2 \mathrm{~m}$ deep and are frozen below $10-20 \mathrm{~cm}$. After examining sampling options, we decided to build our own corer, improving upon previous designs, such as the SIPRE/CRREL corer designed by the Snow, Ice and Permafrost Research Establishment, U.S. Army Corps of Engineers, which later became Cold Regions Research and Engineering Laboratory. Their designs are described in Ueda et al. (1975), Brockett and Lawson (1985), and Department of the Army (2001) and references therein. Our design improves upon a similar SIPRE/CRREL type corer described by Hughes and Terasmae (1963), which was used and modified extensively by the Geological Survey of Canada (GSC) in the 1960s and 1970s (Blake, 1964, 1974, 1977; Veillette and Nixon, 1980). The motorized corer described by Hughes and Terasmae was based on improvements made to a hand-operated, SIPRE-type ice corer manufactured by AB Stålsvets, Sollentuna, Sweden. The corer that Hughes and Terasmae (1963) used in the Yukon in 1962 had teeth of tool steel. Blake (1964) replaced these with teeth made of Carboloy (an alloy containing cobalt, tungsten, and carbon), noting excellent results.

\footnotetext{
${ }^{1}$ University of Southern Denmark, Department of Chemistry, Campusvej 55, DK-5230 Odense M, Denmark

${ }^{2}$ Corresponding author: meg @ chem.sdu.dk; previous address: National Environmental Research Institute, Department of Atmospheric Environment, Frederiksborgvej 399, DK-4000 Roskilde, Denmark

${ }^{3}$ Institute of Environmental Geochemistry, University of Heidelberg, INF 236, D-69120 Heidelberg, Germany; previous address: Geological Institute, University of Berne, Baltzerstrasse 1, CH-3012 Berne, Switzerland

(C) The Arctic Institute of North America
} 


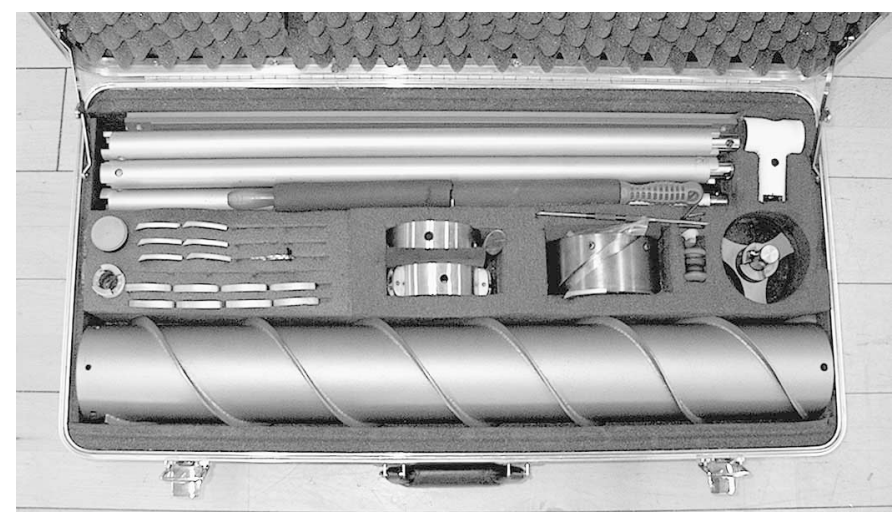

FIG. 1. The complete coring kit in its field case, minus the motor, fuel, and core packing tubes.

Visually, the new corer looks similar to the Austin Kovacs Enterprises (AKE) MARK V Ice Corer. However, the AKE MARK V corer is designed for coring ice, and the materials used to construct it (stainless steel cutting teeth, anodized aluminum cutting head, fiberglass barrel) render it unsuitable for coring frozen peat, which might contain sand or other mineral particles (A. Kovacs, pers. comm. 2000), or for sampling the substrate immediately below the organics. Visual inspection of the peat cores from Bathurst Island collected by Blake in 1963 revealed abundant grains of mineral material, clearly indicating the need for robust coring equipment using suitable construction materials. Because there was no commercially available corer for collecting undisturbed cores of frozen peat, we decided to design and build our own. After a prototype corer had been built, we compared it to a GSC corer as described in technical drawings kindly provided to us by W. Blake, Jr. However, we have remained with our original design, because of the improvements described below.

\section{NEW CORER DESIGN AND FEATURES}

The new corer (Fig. 1) is a rugged, Teflon ${ }^{\circledR}$-coated coring system that can continuously core frozen peat up to $10 \mathrm{~m}$ deep in $70 \mathrm{~cm}$ long sections of $9.7 \mathrm{~cm}$ diameter. The complete system (minus motor and fuel) weighs $26 \mathrm{~kg}$. This weight includes $10 \mathrm{~m}$ worth of treated aircraft aluminum extension rods that are connected with male and female locking flange ends. These locking ends transfer the torque and are secured with a locking pin, in case the flanges deform or break. The system includes a core recovery system as a back-up and extra cutting teeth. Thus, one person can easily carry the complete corer. The corer is powered by a motor (one-man, $1.6 \mathrm{hp}$ or two-man, $4.1 \mathrm{hp}$ ) that allows a $70 \mathrm{~cm}$ core section to be recovered in approximately 15 minutes (including packing time).

Our system includes a quick-release coupling system to connect the motor drive shaft to the corer tube (Fig. 2) so that samples can be removed before they freeze into the Teflon®-coated, stainless steel (AISI 304) coring tube.

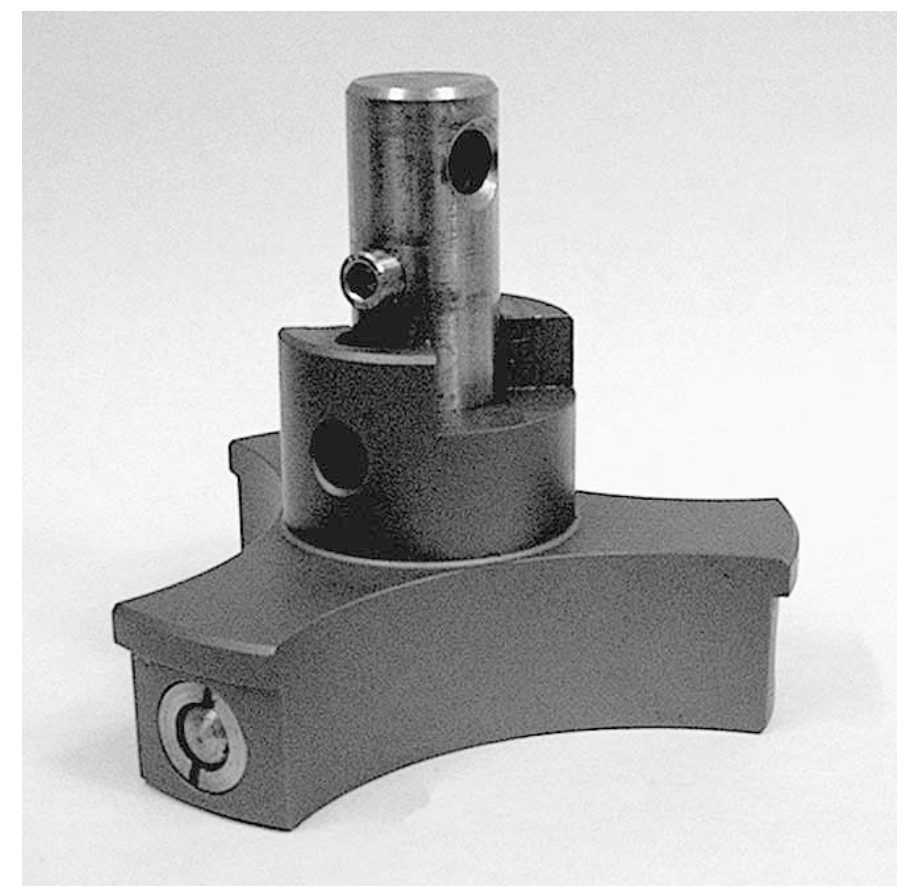

FIG. 2. Quick-release coupling system to connect the motor drive shaft to the corer tube. It is important to remove the corer from the coring tube as quickly as possible so the cores will not freeze into the tube. The quick-release coupler locks and unlocks the motor to the coring tube with the press of one button, and it has just three connecting points.

The coating helps prevent the samples or chips of peat from freezing to the tube. Moreover, the hardened (Rockwell 62) steel (Sverker® 21) cutting teeth cut the core $5 \mathrm{~mm}$ smaller than the tube diameter, allowing the core to slide easily into commercial polyethylene (PE) stockings. These are sealed, labeled, and placed in capped plastic tubes whose diameter allows the cores to fit snugly, helping to protect them from deformation during shipping and storage.

The complete coring kit cost us approximately US $\$ 8000$ to build, including parts and labor, with the motor an additional expenditure. The kit weighs $26 \mathrm{~kg}$ (minus the motor, fuel, and core packing tubes). The kit as shown (Fig. 1) contains enough treated aircraft-aluminum extension rods to core a frozen peat deposit $10 \mathrm{~m}$ deep. It includes extra sets of teeth, maintenance tools, a manual core recovery system, attachments to turn the core manually if necessary, and a plastic pusher attachment (for an extension rod), to manually push the core out of the tube into the polyethylene (PE) sock. A one-man motor (1.6 hp), $150 \mathrm{rpm}$, weighs approximately $6.8 \mathrm{~kg}$, and a two-man motor (Stihl BT 360, $4.1 \mathrm{hp}$ ) weighs $25.9 \mathrm{~kg}$. The gear reduction unit on the Stihl motor provides $50 \mathrm{rpm}$. Depending on the motor type and operating conditions, generally a half-kilogram of fuel is sufficient for several hours of operation. Packing material (high-density plastic core tubes with end caps) weighs an additional $3 \mathrm{~kg}$. The cores themselves $(70 \mathrm{~cm} \times 9.7 \mathrm{~cm})$ will weigh between $5 \mathrm{~kg}$ (pure frozen peat with bulk density of $1 \mathrm{~g} / \mathrm{cm}^{3}$ ) and $14 \mathrm{~kg}$ (sediment of bulk density $2.65 \mathrm{~g} / \mathrm{cm}^{3}$ ). 


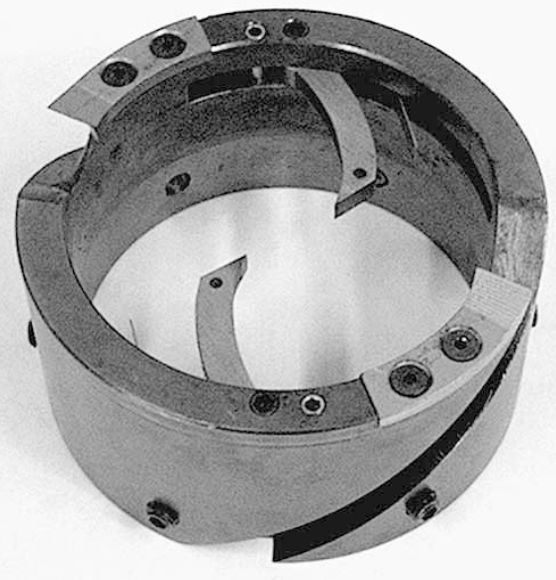

FIG. 3. Spring-loaded cutting blades on the inside of the cutting head cut through the bottom of the core when the motor is stopped and the rotation is manually reversed. Blades can easily be replaced or sharpened in the field. They are thick enough to bear the weight of the core when it is lifted out of the hole.

Our coring system also includes spring-loaded cutting blades on the inside of the cutting head (Fig. 3), which are designed to cut horizontally across the bottom of the core section when the rotation is reversed. At rest, the core cutting blades remain protracted. When rotating in the coring direction (counterclockwise in Fig. 3), they catch on the soil and are forcibly retracted into the coring head against the springs. When the rotation is reversed (clockwise in Fig. 3), the spring forces them to catch into the core. Thereafter, they cut towards each other through the core because of the outside angle of the cutting blades, as seen in Figure 3.

This important feature therefore quickly and uniformly undercuts the bottom of the core section; moreover, these cutting blades support the peat core while it is being recovered from the hole. Therefore, the corer provides an effectively continuous record of peat accumulation, a feature that is especially important in palaeoenvironmental studies.

In addition, the coring system includes a manual core recovery system, designed at the GSC (as depicted in Veillette and Nixon, 1980; Blake, 1982). This compact backup system can be assembled in the field in case it is needed. The kit consists of rods and two circular plates with three grabbing teeth on the plate at the bottom, and it includes a conical metal wedge, which is attached to the end of the extension rods. Sliding the wedge forcefully between the core and the borehole sidewall causes the core to break near the bottom. The wedge is removed, and the extension rods are attached to the core recovery frame described above. The frame slides over the core and is gently pulled up, catching the teeth into the core, which is then lifted to the surface. We did not experience our motorized corer getting stuck or fouled with sediment in the coring process in the field.

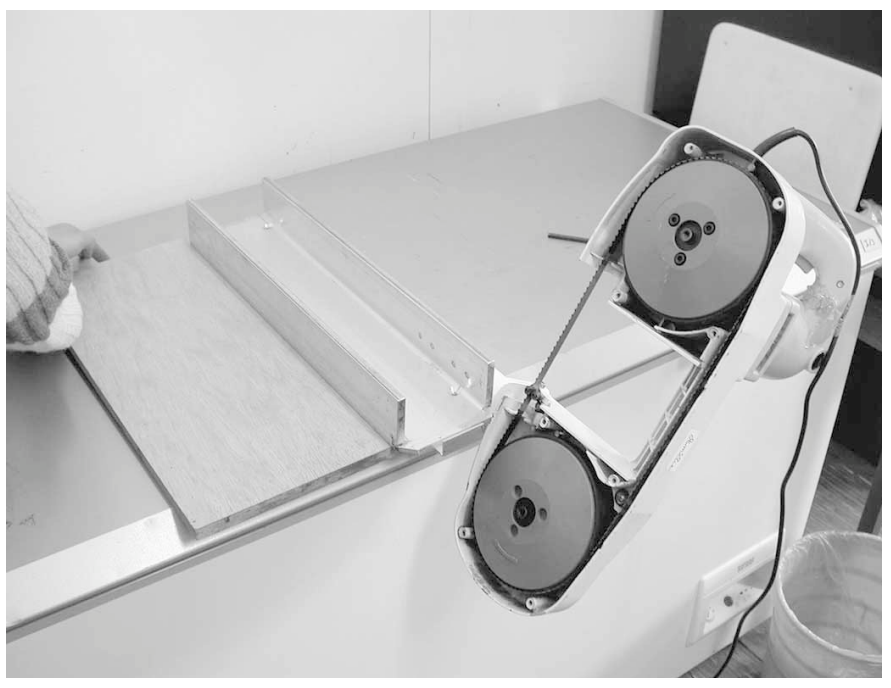

FIG. 4. Horizontally hinged band saw mounted on an aluminum frame, with adjustable backstop for varying the slice thickness. When it is judged safe to do so, and as a necessary requirement for lowest possible cross-contamination of slices, the bottom cover of the band saw is removed during operation to allow quick and easy cleaning between slices so that debris does not accumulate.

\section{SAMPLE PROCESSING}

In the laboratory, a slicing and volumetric sub-sampling system was designed and constructed to facilitate uniform sectioning of the frozen core, with easy access for cleaning between slices to reduce the risk of contamination and allow for easy blade replacement. Our cores are usually cut into sections of $1 \mathrm{~cm}$, but the saw system can be adjusted to any thickness required. Prior to developing this system, we had sliced cores with a vertical band saw on a sliding board. Unfortunately, the band saw retains debris in the blade housing and there is a risk of cross contamination between samples. Because of the potentially large differences in pollutant concentrations between modern and ancient peat samples, the risk of contamination is a serious drawback that needs to be reduced as much as possible. To overcome this problem, we mounted a commercially available band saw on a custom core guide and stop (Fig. 4). A peat core is placed within the frame of the core guide and slid to the backstop after each slice, thus providing slices of uniform thickness. Because the saw blade is mounted horizontally, the debris generated during cutting will fall into a waste basin. As an extra precaution to further reduce the risk of contamination, the saw blade can be rinsed each time without removing any blade housing covers. This poses a safety hazard, which must be evaluated for each saw type, and it requires thorough pre-examination and tightening of the saw blade. It is also possible to allow the cover to be attached during sawing and remove it each time, as long as the saw is set up in a cold room to prevent the core from thawing.

For trace contaminant research, sub-samples are taken from the inner part of the core, staying away from the edges that might have been perturbed during coring. Frozen slices are sub-sampled uniformly with a hand- 


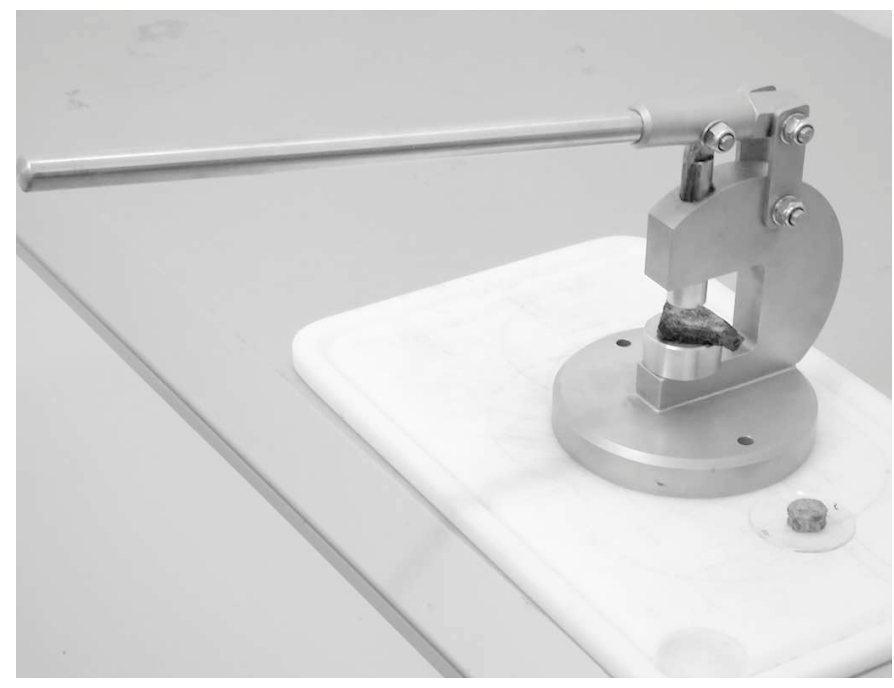

FIG. 5. The stainless steel (AISI 304) press for volumetric sub-sampling of frozen slices. A sub-sample is shown on the watchglass beside the machine. A portion of the slice remains on the press.

operated stainless steel (AISI 304) press, which recovers volumetric plugs for further analysis (Fig. 5). These plugs are then used as is for measurements of physical properties, such as moisture content and bulk density, and for recovering plant macrofossils for ${ }^{14} \mathrm{C}$ age dating. Plugs can also be dried and milled to provide a homogeneous fine powder for subsequent chemical analyses and for ${ }^{210} \mathrm{~Pb}$ age dating.

\section{FIELD WORK}

The Environmental Chemistry Research Group at the University of Southern Denmark, in collaboration with the Institute for Environmental Geochemistry at the University of Heidelberg, the Danish National Environmental Research Institute (NERI), the University of Berne, and the Geological Survey of Denmark and Greenland (GEUS), are investigating long-term records of contaminants $(\mathrm{Hg}$, $\mathrm{Cd}, \mathrm{Pb}$ and polycyclic aromatic hydrocarbons [PAHs]) in the Arctic, using permanently frozen peat deposits as environmental archives. The sites chosen to date are on Bathurst Island, Nunavut, Canada, and Nordvest $\varnothing$, Carey Islands, Greenland. The choice was based on previous investigations at the sites undertaken by the Geological Survey of Canada (GSC) approximately 30-40 years ago (Blake, 1964, 1974, 1977; Brassard and Blake, 1978). The verified stratigraphy, physical, palynological and paleoecological (e.g., Brown et al., 1994) determinations in the peat deposits made the sites good candidates for the present study, as did the advice offered by Dr. Weston Blake, Jr., with respect to the sites and coring experiences. The excellent field descriptions provided by Dr. Blake enabled us to return to the exact sites where he had cored near his site at Bracebridge Inlet and actually find the stillcapped boreholes left after his investigations on location at

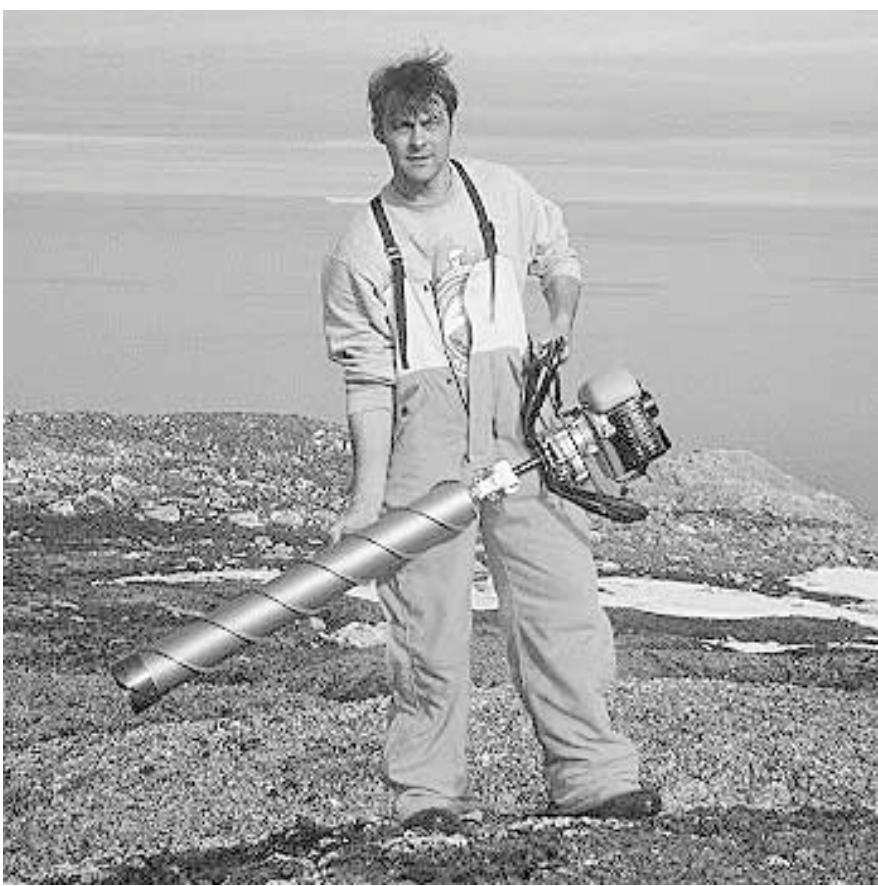

FIG. 6. Tommy Nørnberg standing on top of a peat mound at the Nordvest $\varnothing$ peat site (July, 2001), with the assembled corer and one-man (1.6 hp) motor. Although one person can operate the corer, a two-person team is the minimum necessary for safe field operations in Arctic conditions. Having two people also expedites the labeling and packing of the cores.

Nordvest $\varnothing$. By sampling at or near the previous sites, we were able to obtain information that supplements and complements information taken from cores in the previous studies.

\section{CONCLUSION}

Our sampling system is the result of laboratory testing prior to our Bathurst Island campaign during the summer of 2000, field-testing on Bathurst Island, subsequent improvements and testing before the Carey Islands trip, and satisfactory field use in the Carey Islands in 2001 (Fig. 6). Our coring system met or exceeded the original design goals: 1) It is portable and can easily be carried by an individual; 2) It recovers continuous cores as long as necessary; 3) It functions well in the Arctic environment, with all equipment amenable to service delivered in the field while wearing gloves, including replacement of the cutting head teeth; 4.) It is robust, with all components designed to survive overland transport, weather extremes, and the wear and tear associated with coring peat that contains high concentrations of mineral matter; and 5) It is adaptable. In addition to coring peat, this corer is equally effective in recovering ice from lenses and mineral matter (sand and silt) when present. Thus, it should be very useful for recovering a broad range of Quaternary materials frozen in the Arctic. 


\section{ACKNOWLEDGEMENTS}

Further information about the coring and preparation system described here is available without cost from the senior author (tno@ chem.sdu.dk) or can be downloaded from the University of Heidelberg Institute of Environmental Geochemistry link to the research theme "Peat Bog Archives of Atmospheric Deposition": http://www.rzuser.uni-heidelberg.de/ i12/nicolasgivelet.htm.

Development of this system was made possible by financial support from the Danish Environmental Protection Agency, as part of the environmental support program DANCEA (Danish Cooperation for Environment in the Arctic), and from the University of Southern Denmark, Department of Chemistry. Stihl GmbH (Switzerland and Sweden) provided us with a BT 360 two-man motor and extension rods for initial laboratory and field-testing of the prototype corer, as well as relevant technical specifications. An International Arctic Research Center (IARC) grant to W. Shotyk provided for the fieldwork on Bathurst Island and for this work, and Stihl Canada lent us a BT 360 two-man motor and provided technical manuals, oil, and spare parts (thanks to K. Eberle, G. Quigg, and E. Zynomirski). Special thanks to Weston Blake, Jr., for his assistance while we were preparing the sampling plans and testing and building the corer, for providing his original peat cores from Bathurst Island for testing, and for his critical reading of this manuscript. For the fieldwork phases, we would like to thank our scientific colleagues A. Cheburkin, O. Bennike, and E. Warncke. We gratefully acknowledge the help from team members who did not take part in the fieldwork, especially Prof. C. Lohse, N. Givelet, G. Le Roux (especially Figs. 4 and 5), and P.B. Hansen. M. Goodsite was supported by a Ph.D. fellowship from NERI and the Danish Research Agency, as a graduate student at the University of Copenhagen (Global Change Initiative Graduate School) under the academic supervision of H. Skov, S. Lindberg, and O.J. Nielsen, for which he is most grateful. Special thanks to three anonymous reviewers for helping to improve the manuscript.

\section{REFERENCES}

BLAKE, W., Jr. 1964. Preliminary account of the glacial history of Bathurst Island, Arctic Archipelago. Geological Survey of Canada Paper 64-30. 8 p.

1974. Periglacial features and landscape evolution, central Bathurst Island, District of Franklin. In: Report of Activities, Geological Survey of Canada Paper 74-1B. 235-244.

- 1977. Radiocarbon age determinations from the Carey Islands, Northwest Greenland. In: Report of Activities, Part A, Geological Survey of Canada Paper 77-1A. 445-454.

- 1982. Coring of frozen pond sediments, east-central Ellesmere Island: A progress report. In: Current Research, Geological Survey of Canada Paper 82-1C. 104-110.

BRASSARD, G.R., and BLAKE, W., Jr. 1978. An extensive subfossil deposit of the arctic moss Aplodon wormskioldii. Canadian Journal of Botany 56:1852-1859.

BROCKETT, B.E., and LAWSON, D.E. 1985. Prototype drill for core sampling fine-grained perennially frozen ground. CRREL Report 85-1. Hanover, New Hampshire: U.S. Army Corps of Engineers, Cold Regions Research and Engineering Laboratory.

BROWN, K.M., DOUGLAS, M.S.V., and SMOL, J.P. 1994. Siliceous microfossils in a Holocene, High Arctic peat deposit (Nordvest $\varnothing$, Northwestern Greenland). Canadian Journal of Botany 72:208-216.

DEPARTMENT OF THE ARMY. 2001. Sampling frozen soils. In: Engineering and Design: Geotechnical Investigations. U.S. Army Corps of Engineers Manual No. 1110-1-1804. Chapter F-9-111. Available online at http://www.usace.army.mil/inet/usacedocs/eng-manuals/em1110-1-1804/appendF-09.pdf

HUGHES, O.L., and TERASMAE, J. 1963. SIPRE ice-corer for obtaining samples from permanently frozen bogs. Arctic 16(4):270-272.

UEDA, H., SELLMANN, P., and ABELE, G. 1975. USA CRREL snow and ice testing equipment. Special Report 146. Hanover, New Hampshire: U.S. Army Corps of Engineers, Cold Regions Research and Engineering Laboratory.

VEILlETTE, J.J., and NIXON, F.M. 1980. Portable drilling equipment for shallow permafrost sampling. Geological Survey of Canada Paper 79-21. 35 p. 